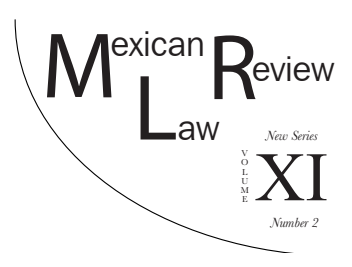

\title{
CRIMINAL JUSTICE, DUE PROCESS AND THE RULE OF LAW IN MEXICO
}

\author{
Paola I. DE LA Rosa RodRÍGUEZ*
}

\begin{abstract}
The criminal justice process should not involve obtaining the truth at any price. This article discusses how Mexico has adopted exceptional regulations which violate due process considerations and create a problematic breach of the rule of law. We argue that, at a time when Mexican society suffers the consequences of organized crime, the Constitution provides for two types of regulations: one protecting human rights, which are the foundation of the rule of law; and another which infringes on the individual rights of those suspected of having participated in organized criminal activity.
\end{abstract}

We examine mechanisms such as preventive detention and preventive imprisonment and analyze their treatment under Mexican law as well as in international agreements. We explore whether or not the fight against criminality and the prosecution of criminals "by any means necessary" is more important that the protection of the human rights of those suspected of illegal activity. We conclude by suggesting that the response to criminality should not require limitations on the constitutional freedoms of citizens.

KeYwords: Organized crime, prosecution of crime, human rights, preventive detentions, rule of law.

RESUMEN: En un proceso penal no se debe obtener la verdad a cualquier precio. Este artículo establece que México ha adoptado un procedimiento en el que se permite el quebrantamiento del estado de derecho. En una época en la que México sufre las consecuencias del crimen organizado la Constitución permite dos tipos de reglas de procedimiento penal, una que protege los derechos humanos y otra que los restringe. Con este propósito se examinan figuras tales como el arraigo y la prisión preventiva así como su regulación en la norma mexicana y en los tratados internacionales. El artículo analiza si el uso de métodos represivos en la investigación y combate al crimen organizado es más importante que la protección de los derechos humanos de los presuntos responsables de haber

* Professor, Law School, Autonomous University of San Luis Potosí. Email: attypdlr@gmail.com. 
Esta revista forma parte del acervo de la Biblioteca Jurídica Virtual del Instituto de Investigaciones Jurídicas de la UNAM http://www.juridicas.unam.mx/ https://biblio.juridicas.unam.mx/bjv https://revistas.juridicas.unam.mx/ http://dx.doi.org/10.22201/iij.24485306e.2019.1.13131

cometido ese tipo de conducta. En este sentido, se sugiere que la respuesta a la criminalidad no debe limitar las libertades individuales de los ciudadanos.

Palabras clave: Crimen organizado, investigación del delito, derechos humanos, prisión preventiva, estado de derecho.

TABLE OF CONTENTS

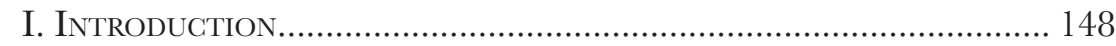

II. How Constitutional Reforms Impact Human Rights ................... 149

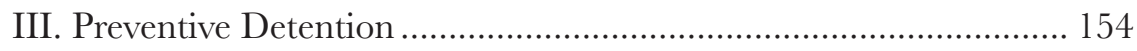

IV. The Impact of Preventive Detention on Human Rights ........... 156

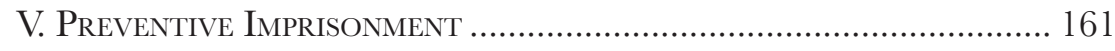

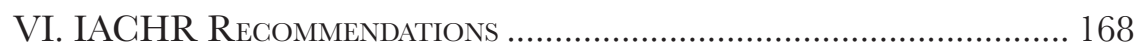

VII. Gonclusions ........................................................................... 170

\section{INTRODUCTION}

The rule of law and due process should be paramount in democratic regimes where state power is supposed to be checked by the defense of freedom, in societies in where the law is supreme and, therefore, prevails above all, including government institutions. In such settings, legislative bodies have the obligation to create rules that guarantee and respect the human rights of all people. It is the responsibility of judicial officials to interpret such rules to ensure that those rights prevail even over the expectations of the parties involved in a conflict, including the state itself. Therefore, it is essential that both the rules of the state as well as the actions of the authorities applying said rules recognize, promote, and enhance basic rights.

The difficulty in following these principles in countries like Mexico lies in the fact that the constitutional reform of 2008, implementing the accusatorial legal system, was adopted at a time when criminal activity had increased significantly. Casas reported, following a study conducted by The Center of Investigation for Development (CIDAC), that Mexico ranked number 16 among 115 countries with the highest rates of violence in the world. ${ }^{1}$

According to Buscaglia, the change of political party in 2000 strengthened both ordinary and organized criminality. ${ }^{2}$ In this scenario, the emphasis of

\footnotetext{
1 Maria Casas Perez, Cobertura informativa de la violencia en México, 8 Global Media Journal México, 6 (2011).

2 Doris Gómora, Crimen se fortaleció a partir del gobierno de Fox: Buscaglia, El UnIVERsaL, November 22, 2014, (May 18, 2018), http://archivo.eluniversal.com.mx/nacion-mexico/2014/impreso/ crimen-se-fortalecio-a-partir-del-gobierno-de-fox-buscaglia-220572.html.
} 
the government security institutions was focused on second one. ${ }^{3}$ As a consequence, the lawmakers' discussions before the adoption of constitutional reforms in 2004 and in 2007, emphasized this problem. ${ }^{4}$

One of the reasons that helps explain the current situation in Mexico lies in the fact that most of the criminal and security sector reforms carried out in Mexico, beginning in the late eighties and continuing into the nineties, did not envisage a transformation of the public security, justice or defense systems. ${ }^{5}$ Along with non-compliance with due process, there has also been an absence of adequate laws, among other factors. ${ }^{6}$ With this in mind, in this article, we develop an analysis of two legal figures that exist to combat criminal organizations: preventive detention and preventive imprisonment. We then question if these measures comply with the most recent constitutional reforms regarding human rights. The purpose of this article is to discuss whether the state gives more importance to human rights or to the adoption of repressive mechanisms aimed at combating organized crime.

The reason why this research is focused on preventive detention and preventive imprisonment is due to the fact that criminal investigation activities have been the object of complaints before different national and international human rights institutions. Additionally, Mexico has received numerous recommendations aimed at restricting the use of this type of force over individuals.

With this in mind, we analyze the Mexican constitutional reforms of 2008 and 2011. In order to support the facts presented in this article, we make reference to statistical data on Mexican organized crime rates, and examine the use of repressive measures and the number of complaints received by human rights organizations. We also analyze the existing social and legal background in which the aforementioned legal figures were adopted in Mexico, and compare these prosecution methods to the content of international treaties and the recommendations of regional and global human rights agencies.

\section{How Constitutional Reforms Impact Human Rights}

The accusatorial system was put into effect in most countries in Latin America in the last two decades of the 20th century, introducing a protective regime for individuals under the criminal justice system. According to Binder,

3 The Mexican Constitution included and defined the figure of organized crime in 1993; the concept and scope of organized crime became so important that three years later, in 1996, congress created the Federal Act Against Organized Crime.

4 Sergio García Ramírez, Reseña legislativa sobre la reforma constitucional de 2007-2008 en materia de seguridad pública y justicia penal, 123 Boletín Mexicano de Derecho Comparado, 1557-1581 (2008).

5 Raúl Benitez Manaut, La crisis de seguridad en México, 220 Nueva sociedad, 174 (2009).

6 Phil Williams, El crimen organizado y la violencia en México: una perspectiva comparativa, 11 IsTOR: REVISTA DE HISTORIA INTERNATIONAL, 37 (2010). 
Esta revista forma parte del acervo de la Biblioteca Jurídica Virtual del Instituto de Investigaciones Jurídicas de la UNAM http://www.juridicas.unam.mx/ https://biblio.juridicas.unam.mx/bjv https://revistas.juridicas.unam.mx/ http://dx.doi.org/10.22201/iij.24485306e.2019.1.13131

it was a regional legal reform process inspired by principles of democracy, and one that pushed towards social reorganization. The adversarial system is a salient feature of modern states, as it recognizes the accused has substantive, procedural human rights. ${ }^{7}$ Specifically, the accusatorial and adversarial system intends to balance two conflicting interests: on one side, legal prosecution and on the other, respect of the rights of the accused. ${ }^{8}$

In tandem with the demands of the Mexican society to move towards fairer judicial procedures, ${ }^{9}$ a reform on public security and criminal justice was enacted in 2008. ${ }^{10}$ Some of the less informed supporters of the reform considered that the reduction of criminality was the main purpose of the accusatorial and adversarial system. After several discussions, Congress passed legal provisions that attempted to respect the human rights of the accused and to reduce organized crime, within the same set of legal changes. ${ }^{11}$ More precisely, whereas the creators of the Mexican Constitutional reforms were in favor of the progressive development of human rights ${ }^{12}$ and encouraged guaranteeing the fundamental rights of individuals, they also attempted, within the same set of amendments, to enhance public security and combat organized crime ${ }^{13}$ Evidencing this purpose, new legal dispositions were published June 18, 2008 titled: "Constitutional Reform on Criminal Justice and Public Security."

The new reform on public security and criminal justice provisions served as a trigger for the establishment of a new guarantee based criminal justice system designed to aid in the fight on crime. ${ }^{14}$ These legal provisions contemplate new rights for the accused, including presumption of innocence, the right to be heard in a trial, a prohibition regarding the use of illegally obtained evidence, and the right to have one's sentence explained in a public audience, among others. It is a reform that incorporates into Mexican law the rights and principles recognized by the Universal Declaration of $\mathrm{Hu}-$

\footnotetext{
7 Alberto M. Binder, La justicia penal en la transición a la democracia en América Latina, (1994). at http://biblioteca.org.ar/libros/133155.pdf visited 10 December, 2017.

8 Miguel Angel Oviedo Oviedo, Tipos de procesos penales o sistemas penales, in Juicios Orales EN México coord. Alfredo Islas Colin, Freddy Dominguez Narez \& Mijael Altamirano Santiago 75 (Flores editor y distribuidor 2014).

9 The main causes of the movement behind the constitutional reform towards an accusatorial and adversarial system were: frequent infringement of the accused individual rights', lack of confidence in the government institutions investigating criminality and the fact that most crimes stayed unpunished.

10 Guillermo Zepeda-Lecuona, La reforma constitucional en materia penal de junio de 2008. Claroscuros de una oportunidad histórica para transformar el sistema penal mexicano, REV.A.PLU., ITESO, 113 (2008).

11 GARCía, supra note 3.

12 Rafael Aguilera Portales \& Rogelio López Sánchez, Los derechos fundamentales en la Teoría Furídica garantista de Luigi Ferrajoli, 56 IUSTITI, 157-206 (2008).

13 Hermes Prieto Mora, Marketing pro-guerra en México, 16 Fórum DE RECERCA, 363 (2011).

14 Eduardo Martínez Bastida, El derecho penal del enemigo en las reformas constitucionales. 4 ARCHIVOS DE CRIMINOLOGÍA, CRIMINALÍSTICA Y SEGURIDAD PRIVADA, 62 (2010).
} 
man Rights, the International Covenant on Civil and Political Rights and the American Convention on Human Rights.

Clearly, this was a historic constitutional reform for Mexico. History can move forward or backwards, and these legal changes moved both ways: they moved forward by implementing an accusatorial and modern criminal system, and backwards in terms of individual rights and liberties. ${ }^{15}$ The drawback of these movements is that the Mexican criminal justice system can now be categorized under two types of procedures. In other words, after having had just one criminal justice regime, we now have an ordinary system where the rights of the accused are respected, as well as a special procedure designed to fight against organized crime under which individuals can actually be deprived of their rights. The strict application of some of the protective provisions has resulted in the acquittal of serious criminals, ${ }^{16}$ consequently, the fight against organized crime has prevented full compliance with the standards protecting human rights that Mexico had adopted in recent constitutional reforms. We thus disagree with the statement that "the protection of human rights is totally consistent with public security." 17

In this context, we argue that while the debate about the protection of the fundamental rights of the accused in the context of the search for the truth continues, we are faced with the issue of determining whether the state must guarantee the protection of basic rights in a society in which organized crime is strongly rooted. Ledesma has noted that states have the commitment to protect human rights, ${ }^{18}$ however, the actual debate involves analyzing if the legislature is giving more importance to the fight against organized crime or to the respect of the fundamental rights of those suspected of carrying out illegal acts.

In considering the amendments to the law, even though human rights regulations within the Mexican Constitution were ample, it was necessary to modernize the $20^{\text {th }}$ century text according to evolving historical, social, institutional and international contexts; at the same time there was a need to ensure the incorporation of international treaties into domestic law. ${ }^{19}$ With

15 Oviedo, supra note 7, at p 75.

16 Just to mention one example, on April 29, 2010 a Court in Chihuahua acquitted Sergio Barraza Bocanegra after confessing before a police officer he had murdered his girlfriend Rubí Frayre Escobedo and placed her 39 body parts in a dumpster. That declaration was considered invalid in Chihuaha Criminal Procedures Code.

17 Alfredo islas colin, DeClaraciones En EL FORO REFORMa PENAL Y DEMOCRACIA EL Dia 5 SEP 2007 Juicios Orales en MéXico tomo I (Flores editor y distribuidor 2014).

18 Héctor Faúndez Ledesma, Sistema Interamericano de Protección de los Derechos Humanos. Aspectos Institucionales y Procesales (Instituto Interamericano de Derechos Humanos 2004).

19 Víctor M. Martínez Bullé-Goyri, Reforma constitucional en materia de derechos humanos, 44 BoletíN MEXICANo de DERECho COMPARADo, 405-425 (2011), (Aug. 12, 2017), http://wrew.scielo.org. $m x /$ scielo.php?script $=$ sci_arttextEpid $=S 0041-86332011000100012$ Eंng $=e s$ E'tlng $=e s$. 
Esta revista forma parte del acervo de la Biblioteca Jurídica Virtual del Instituto de Investigaciones Jurídicas de la UNAM http://www.juridicas.unam.mx/ https://biblio.juridicas.unam.mx/bjv https://revistas.juridicas.unam.mx/ http://dx.doi.org/10.22201/iij.24485306e.2019.1.13131

what appeared to be a growing concern to promote individual rights, the Congress of the Union enacted a human rights reform in 2011.

In the new Article 1 of the Constitution, the government seems to have adopted an ample approach driven by the protection of human rights. It establishes that all authorities must promote, respect, protect and ensure human rights and carry out the state's commitment to prevent, investigate, punish and repair any human rights violation. ${ }^{20}$ According to pro persona principle, every authority, including state and public institutions, must apply norms providing individuals the widest protections. The amendment established that the international treaties signed by the Mexican government in the matter of human rights will be incorporated into the block of constitutionality limits, which no power can restrict or suspend, except in cases and conditions established in the Constitution. ${ }^{21}$ It also establishes that every legal provision regarding human rights shall be interpreted according to the Constitution and international treaties. $^{22}$

The 2011 reform evidenced the human rights weaknesses of the constitutional text and it demonstrated a supposed conviction to make individual rights prevail over any other legal provision, nevertheless, in 2013 the Supreme Court of Justice examined Case 293/2011 and determined that even though the block of constitutionality exists and is integrated by the human rights included both in the Constitution and in international treaties, if the international norm is not consistent with the constitutional norm, it is the constitutional norm that will prevail. This interpretation was considered by members of academia and attorneys as a historic step backwards, leading to restrictions to the pro persona principle.

To analyze the existing environment of these changes, it is worth mentioning that along with the adoption of these constitutional reforms, many of the criminal acts taking place in Mexico are organized violent acts. According to the report titled Situación de los derechos humanos en México, it is corruption and impunity in Mexico, as well as in several countries in Latin America, that have strengthened organized crime networks. ${ }^{23}$ The magnitude of the problem is such that organized criminal groups engage not only in drug trafficking, but also in other illegal activities such as human and migrant trafficking, trafficking of protected natural resources, the illegal arms trade and extortion. ${ }^{24}$ The growing amount of illegal activities carried out by criminal groups has

20 Sergio García Ramírez \& Julieta Morales Sánchez, La reforma constitucional SObre derechos humanos (2009-2011), $3^{\text {a }}$ ed., Porrúa, UNAM, (2013).

21 José de Jesús Orozco Henríquez, Los derechos humanos y el nuevo artículo 1 constitucional, 5 Rev. Ius. 28, 85-98 (2011).

22 Martinez Bullé-Goyri, supra note 18 , at 410.

23 CIDH \& OEA, Situación de los derechos humanos en México, Colección Comisión Interamericana de Derechos Humanos OEA/Ser.L./V/II.Doc.44/15, (Nov. 2, 2017), at https://archivos. juridicas.unam.mx/werw/bjv/libros/10/4618/4.pdf.

24 Id. at p. 6. 
empowered them, while the government is held responsible for the lack of effective strategies in response to rising organized criminality. ${ }^{25}$

Since the early 2000 s, the term "organized crime" has been consistently included in documents and strategies on national and public security, ${ }^{26}$ as well as in the reports of international organizations. ${ }^{27}$ The Federal Act Against Organized Crime established a special regime for the investigation, prosecution, sanction, and enforcement of crimes within this category. This Act increased the number of penalties against criminal associations and allowed for measures such as surveillance and phone tapping. ${ }^{28}$ Other new elements include the use of undercover agents and the confiscation of property. Since the adoption of this Act, Mexico has created new criminal policy aimed at strengthening the intensive battle against organized crime, which is often characterized by the absence of responsibility and accountability on the part of local authorities. ${ }^{29}$

Additionally, in 2016 the Federal Act Against Organized Crime resulted in changes to more than thirty three or its own articles, with the stated purpose of confronting criminal associations. For instance, the number of illegal activities punished as organized crime increased, as did the terms of imprisonment. The new dispositions place a particular emphasis on the restriction of communications for individuals who are prosecuted and convicted, as well on special surveillance measures for this type of criminality.

Evidently today's reality in Mexico presents a dilemma, since strictly complying with the protection of human rights provisions could overshadow efforts to deal with growing criminal activity and the wave of insecurity that is being experienced in Mexican society. In its attempts to curtail criminal activity, the state is adopting policies that restrict freedoms and foster the arbitrary use of force; the clearest example is that of the war against drug trafficking carried out during the administration of former president Felipe Calderón (2006-2012). ${ }^{30}$ It must be said, however, that in a state governed by the rule of law, and based on the recognition and guarantee of individual rights and freedoms, the use of force must be regulated by rules that distinguish between legal and illegal use of force. In addition, in a nation with the rule of law, the

25 Id.

26 Its inclusion in the Political Constitution, complemented the existing regulation in the Federal Penal Code and in the Criminal Procedure Federal Code.

27 Xavier Servitja Roca, El crimen organizado en México y el 'Triángulo norte' durante el mandato de Felipe Calderón, 3 Instituto Español de Estudios Estratégicos 5 (2012).

28 Jorge Chabat, La respuesta del gobierno de Calderón al desafío del narcotráfico: ENTRE LO MALO Y LO PEOR, CIDE (2010).

29 Javier Carreón Guillén \& Pedro de la Cruz, La lucha actual contra la delincuencia organizada en México 14 Barataria Revista Castellano-Manchega de Ciencias Sociales 70 (2012).

30 Guillermo Pereyra, México: violencia criminal y guerra contra el narcotráfico 74 RevisTa MEXICana de Sociología. 430 (2012). 
Esta revista forma parte del acervo de la Biblioteca Jurídica Virtual del Instituto de Investigaciones Jurídicas de la UNAM http://www.juridicas.unam.mx/ https://biblio.juridicas.unam.mx/bjv https://revistas.juridicas.unam.mx/ http://dx.doi.org/10.22201/iij.24485306e.2019.1.13131

use of force by government authorities, as well as abusive practices, must be gradually restricted or limited.

Rules can be found in the Constitution that allow for arbitrary actions such as preventive detentions and preventive imprisonment, which are inconsistent with respect for human rights. More specifically, the country is adopting a policy consisting of reducing fundamental rights by means of severe control and surveillance, ${ }^{31}$ the legalization of said rules will lead to the increase of such practices.

\section{Preventive Detention}

Preventive detention is a type of arrest carried out when a criminal investigation takes place, long before a formal declaration that someone is guilty of a criminal offense is pronounced by a judge in a court of law. It provides public prosecutors with mechanisms to combat illegal activity.

According to a study titled Arraigo judicial: datos generales, contexto y temas de debate ${ }^{32}$ this type of arrest was established for the first time in the Mexican criminal justice system in 1983, after the reform of the Federal Penal Procedures Code. Since its inception, it was enacted as a preventive measure to guarantee the attendance of accused individuals during preliminary investigations in the criminal justice process. ${ }^{33}$ Preventive detentions were incorporated in the Code of Criminal Procedures for the Federal District and Federal Territories as a tool to allow detentions with the goal of having the detained testify as witnesses to a crime, and in those cases in which a well-founded basis exists to presume that the accused could evade justice.

During the presidential administrations of Ernesto Zedillo and Felipe Calderón, however, this type of custody began to go in a different direction, as it was included in the Federal Act Against Organized Crime as well as in the Constitution, with the purpose of combating criminal organizations. ${ }^{34}$ In fact, organized crime was recognized during those administrations as a national security issue that included the infiltration of government institutions

31 Eduardo Martínez, El derecho penal del enemigo en las reformas constitucionales 4 ARCHIVOS DE CRIMINOLOGÍA, CRIMINALÍSTICA Y SEGURIDAD PRIVADA 68 (2010).

32 Centro de estudios Sociales y de Opinión Pública, Comisión Mexicana de Defensa y Promoción de los Derechos Humanos A.C., Arraigo judicial: datos generales, contexto y temas de debate, (México: LXI Legislatura Cámara de Diputados, 2011).

33 Marco Antonio Díaz de León, El arraigo y la prohibición de abandonar una demarcación geográfica en el Código Federal de Procedimientos Penales, in Primera conferencia internacional sobre apliCACIÓN Y CUMPLIMIENTO DE LA NORMATIVA AMBIENTAL EN AMÉRICA LATINA (FURÍDICAS UNAM, 2002).

34 Cecilia Toledo, El uso e impactos del arraigo en MéXico. Otros referentes para PENSAR EL PAÍS Fundar, (2014). http://fundar.org.mx/otrosreferentes/documentos/DocArraigoOK.pdf visited 10 march 2016. 
in which corruption, money laundering and drug trafficking were involved. ${ }^{35}$ Due to this criminal environment, the Mexican government put forward a set of initiatives, the outcome of which would be the promulgation of the aforementioned Federal Act, which regulated preventive detentions, in order to prosecute these illegal structures. ${ }^{36}$

In 2005 the National Supreme Court of Justice pronounced preventive detentions unconstitutional. ${ }^{37}$ However, one of Felipe Calderón's first actions when he took power was to adopt a strategy to prevent criminality and combat organized crime. ${ }^{38}$ In fact, the legislative initiative established that the Mexican government was committed to combat organized crime with its resources and strengths, permanently and effectively. ${ }^{39}$ Calderón enacted constitutional reforms of criminal justice procedures and public security, whereby the preventive detention provision was introduced in Article 16 of the Constitution. ${ }^{40}$

When dealing with organized crime, the judicial authority, at the request of the prosecutor, may order that a person be held in preventive detention in a facility and for a period of time as provided for by law, up to a maximum of 40 days, if such detention is necessary for the success of the investigation or for the protection of persons or property, or if there is a well-founded risk that the suspect will abscond from justice. This time period may be extended if the Public Prosecution Service demonstrates that the original grounds for preventive detention are still valid. The total period of a preventive detention may not, however, exceed 80 days. $^{41}$

It is sometimes difficult to prove all the elements of conduct that are required so as to consider a criminal act as organized crime. When there exists only the suspicion that three or more people are engaging in illegal activity, preventive detention can be used to prosecute serious crimes. Such legal

35 In the frameowrk of the UN General Assembly Special Session on the World Drug Problem (UNGASS) http://cmdpdh.org/2016/04/declaracion-de-organizaciones-de-la-sociedad-civilde-derechos-humanos-en-mexico-con-relacion-a-los-efectos-nocivos-a-los-derechos-humanos-por-la-inadecuada-politica-de-seguridad-en-el-combate-a-las-d/.

36 Toledo, supra note 33, at 25.

37 Martiarena LeOnar, Incidencia de la Recomendación 2/2012. Arraigo de la CDHDF en la modificación de prácticas violatorias a los derechos procesales por los jueces del TSJDF (TSJDF, 2014).

38 Toledo, supra note 33, at 24.

39 Claudia Gamboa, AnÁlisis de la iniciativa de reforma a nivel constitucional, En materia Penal, PRESENTAda POR el ejecutivo ante el Senado de la República, (Cámara de Diputados 2007) at http://wrere.diputados.gob.mx/sedia/sia/spi/SPI-ISS-21-07.pdf visited 1 october 2016.

40 Toledo, supra note 33 , at 3.

41 Article 16 of the Federal Mexican Constitution 
Esta revista forma parte del acervo de la Biblioteca Jurídica Virtual del Instituto de Investigaciones Jurídicas de la UNAM http://www.juridicas.unam.mx/ https://biblio.juridicas.unam.mx/bjv https://revistas.juridicas.unam.mx/ http://dx.doi.org/10.22201/iij.24485306e.2019.1.13131

reforms aim to introduce new criminal policy alternatives, providing more efficient tools to state authorities in charge of prosecution. ${ }^{42}$

Statistical information on preventive detention issued by state authorities shows that it has been used regularly to prosecute kidnapping, money laundering, human trafficking and terrorism, ${ }^{43}$ in other words, it is used to prosecute organized criminal activity. Between 2008 and 2011 General Attorney's Office reported that preventive detention was used in 1,232 kidnapping investigations, 847 terrorism investigations, 288 money laundering investigations and 205 investigations into human trafficking, all criminal activities considered to involve organized criminality. ${ }^{44}$

The National Supreme Court of Justice (SCJN) determined that local legislatures lack the authority to enact such a law, since it is the exclusive power of the Congress of the Union. Meanwhile, to expand the use of preventive detention, the transitional Article 11 of the decree for which the Constitution was reformed in 2008, enabling a higher degree of power to issue preventive detention orders. Congress also lengthened the list of serious crimes, in response to social pressure linked to the lack of citizen security, thus again increasing the use of preventive detention. ${ }^{45}$ One of the arguments in favor of the adoption of preventive detentions was to provide state authorities (public prosecutors) with mechanisms to allow them to be more efficient when investigating organized crime. However, the outcome of these arguments and legal changes was to restrict human rights, including freedom and personal security.

\section{The Impact of Preventive Detention on Human Rights}

Those who believe in the merits of preventive detention argue that it is necessary to guarantee efficient criminal investigations. This assumption has been criticized by opponents, who assert that the imposition of preventive detention implies the suppression of the freedom of an individual in order to investigate whether he or she participated in an illegal act, and that that free-

42 Reform initiative to articles 16, 21, 22 y 73, fraccion XXI of the Federal Constitution and Fedral Law against Organized Crime, (Feb. 1, 2016), http://wrere.senado.gob.mx/index.

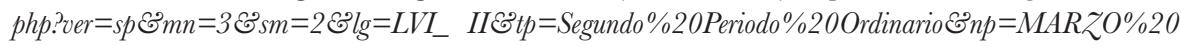
$19, \% 20 \% 201996 \mathcal{E}^{2} d=2$.

43 People held in preventive detention in Federal Investigation Centers by crime, 2008-2011

44 "El arraigo hecho en México: violación a los derechos humanos Informe ante el Comité Contra la Tortura con motivo de la revisión del $5^{\circ}$ y $6^{\circ}$ informes periódicos de México" (Comisión Mexicana de Defensa y Promoción de los Derechos Humanos, A.C. 2012), (Jan. 10, 2017), http://tbinternet.ohchrorg/Treaties/CAT/Shared\%20Documents/MEX/INT_CAT_NGO_ MEX_12965_S.pdf.

45 Amalia Cobos, El arraigo penal en México frente a la presunción de inocencia, Revista PenaL MÉxico, 60 (2015). 
dom constitutes a fundamental right that cannot be restricted until a judge imposes a sanction, upon determination that the person in question effectively participated in the commission of a crime. ${ }^{46}$

From another perspective, preventive detention eliminates the freedom of an individual without the need to obtain evidence that connects him or her to the commission of a crime, since only reasonable indications that a person participated or committed such crime will suffice to submit him or her to detention. ${ }^{47}$ It also ignores the constitutional system of guarantees with regards to personal freedom.

Additionally, this type of arbitrary detention replaces the ordinary rules regarding restriction of personal freedom that requires that a person can only be detained when he or she is caught in the act or with an arrest warrant. It is obvious that the deprivation of freedom cannot be justified unless elements exist to find it probable that the suspect has participated in a wrongful act. This is why preventive detention is arbitrary and unjustifiable.

Another argument against preventive detention is that the presumption of innocence implies the right to receive the consideration or treatment as a non-participant or author of a criminal offense. As Ibañez said, this principle infers a legal status of being identified as an individual not found guilty. ${ }^{48}$ The presumption of innocence can be weakened only at trial based upon legal evidence, empirical elements and rational arguments, never on suspicions or silence. ${ }^{49}$ According to this, demonstrating the innocence of an individual is absurd and the deprivation of freedom is even more so, when the participation of an individual in a wrongful act has not been proven in a trial.

In this context, preventive detentions violate due process, which is supposed to be a fair process. Due process refers to a set of requirements that must be observed in legal proceedings in such a manner that people can have the opportunity to adequately defend their rights in the face of any adverse action of the state. ${ }^{50}$ In this respect, if government restricts the freedom of an individual, this person will not be able to defend himself properly and the restriction of human rights would, without a doubt, preclude having a fair trial. ${ }^{51}$

46 Id.

47 Fernando Silva, El arraigo penal entre dos alternativas posibles: interpretación conforme o inconvencionalidad 33 Revista del Instituto de La Judicatura Federal 243 (2012), at http://fundar.org. $m x /$ trosreferentes/documentos/DocArraigoOK.pdf.

48 Perfecto Ibañez, Presunción de inocencia y prisión sin condena Revista dE LA Asociación de Ciencias Penales de Costa Rica 7 (1996).

49 Rosario de Vicente, Culpabilidad, presunción de inocencia y delitos de sospecha 33 REvisTA Del Poder Judicial. 442 (1994).

50 Sergio García, El debido proceso. Criterios de la Jurisprudencia interamericana (Porrúa 2012), (Jul. 6, 2016).

51 In the international context, the decision in the case of Chaparro Álvarez y Lapo Iñi- 
Esta revista forma parte del acervo de la Biblioteca Jurídica Virtual del Instituto de Investigaciones Jurídicas de la UNAM http://www.juridicas.unam.mx/ https://biblio.juridicas.unam.mx/bjv https://revistas.juridicas.unam.mx/ http://dx.doi.org/10.22201/iij.24485306e.2019.1.13131

As for its impacts, the inclusion of preventive detention in the Mexican Constitution has resulted in an increase of this type of detentions to the extent that the Attorney General recognized that authorities have abused of it since 2008; he pointed out that of 4,000 preventive detentions only 200 suspects had been convicted. ${ }^{52}$ In fact, from 2008 to 2013, of 9,582 suspects held in preventive custody, only 490 were brought before a judge.$^{53}$ Moreover, in 2011 preventive detentions were used to fight the ever increasing number of cases of enforced disappearances. ${ }^{54}$ According to information obtained from the Attorney General by the Centro de Estudios Sociales y de Opinión Pública, in 2009 the Judicial Power authorized an average of twelve preventive detentions per day. In addition, from September 2010 to June 2011, 1 579 civilians were subject to this measure through 453 judicial orders.

The Mexican Commission for the Defense and Promotion of Human Rights (CMDPDH) oversaw more than 405 human rights complaints connected to preventive detentions between 2008 and 2011. Additionally, between January 2008 and December 2013, preventive detentions were used in 9,582 investigations, half of these detentions lasted longer than 40 days. ${ }^{55}$ In 2013, the National Human Rights Commission (CNDH) reported that the Secretary of Defense, the Attorney General and Federal Police were the agencies with the highest number of human rights complaints against them for employing arbitrary use of force, preventive detention, and cruel, inhuman and degrading treatment. ${ }^{56}$ These claims are supported by a CNDH brief on preventive detention and human rights titled Informe sobre el impacto en México de la figura del arraigo penal en los derechos humanos. According to this brief, which was presented to the Interamerican Human Rights Commission, 36 percent of the of the complaints before the CMDPDH involved arbitrary detentions, 39 percent involved torture and other types of abuse and 25 percent were related to both situations. ${ }^{57}$

guez vs. Ecuador in the sentence pronounced November $7^{\text {th }}, 2007$ and in the case of López Álvarez vs. Honduras in the sentence pronounced February 1 $1^{\text {st }}$, 2006. Aside from that, established by the UN Human Rights Council, the Working Group on Arbitrary Detention (1991) has long recognized that with preventive and arbitrary detentions the suspect has no guarantee of the right to a fair process and the right to effective legal protection is denied.

52 I. Navarro, Con Calderón consignaron a 200 de 4 mil arraigados, MiLENIo newspaper, January 30, 2013, at http://wrerc.milenio.com/cdb/doc/noticias2011/visited 20 December 2016.

53 Toledo, supra note 33, at 10.

54 Informe del Grupo de Trabajo sobre desapariciones forzadas o involuntarias, Consejo de Derechos Humanos 19 periodo de sesiones, A/HRC/ 19/58/ Add.2, Numeral 89, p. 18.

55 TolEDO, supra note 33, p. 10.

56 GNDH. Informe de actividades de la Comisión Nacional de Derechos Humanos. Del

$1^{\circ}$ de enero al 31 de diciembre de 2013. (CNDH, México. 2014) p. 17.

57 Comisión Mexicana de Defensa y Promoción de los Derechos Humanos, A.C. (CMDPDH) et. al., 2011. 
Opponents of preventive detentions emphasize that some of the consequences of these arrests and detentions by the police include injuries, bone fractures, beatings and electric shocks. Furthermore, according to the CMD$\mathrm{PDH}$, violations suffered during these detentions also include illegal searches, self-incrimination, lack of communication, arbitrary detentions and torture, ${ }^{58}$ severely diminishing the right of the accused to a fair trial. ${ }^{59}$

Echoing the above, the Subcommittee on Prevention of Torture and other Gruel, Inhuman or Degrading Treatment or Punishment declared in 2009 that the use of preventive detentions in Mexico left detainees in a vulnerable situation without a clearly defined legal status to exercise their legal right to defense. The Special Rapporteur on the Independence of Judges and Lawyers stated, at the end of her official visit to Mexico in 2010, that imposing detention in order to investigate when the appropriate action is to expedite an effective investigation in order to detain, is proof of the dysfunctionality of the justice system and implies a violation of the presumption of innocence. ${ }^{60}$ The Rapporteur considered preventive detention a violation of human rights and stated that it should be eliminated.

Consistent with the assertions in this paper, some of the changes were adopted not only in legislation, in fact, six Specialized Criminal Federal Courts in Searches, Preventive Detention and Communications Tapping (fuzgados Federales Penales Especializados en Cateos, Arraigos e Intervención de Comunicaciones) were created in 2008 in order to prevent, reduce, evade and end national security threats. ${ }^{61}$ These courts were necessary to comply with the adversarial criminal system requiring special judges to authorize precautionary measures and to act in accordance with the National Agreement on Security, Justice and Legality. One year later, the seventh Specialized Court was established, and eight years later, a new Specialized Criminal Federal Court in Searches, Preventive Detention and Communications Tapping was set up in order to authorize the precautionary measures of criminal cases judges exclusively under the new model of justice.

After all these changes, and in spite of the fact that judges are allowed to impose preventive detentions, since it is regulated in the Mexican Constitution, the efficacy of preventive detention in reducing organized crime is still questioned. In this regard, in 2011 the Inter-American Commission on Human Rights (IACHR) presented the results of a study showing that the percentage of convictions derived from a process in which a preventive deten-

\footnotetext{
$58 \quad I d$.

59 TOLEDO, supra note 33, at 405.

60 Human Rights Council, Report of the Special Rapporteur on the independence of judges and lawyers Addendum Mission to Mexico, p. 14 at: https://documents-dds-ny.un.org/doc/ UNDOC/GEN/G11/129/33/PDF/G1112933.pdf?OpenElement. Visited 9 july 2016.

61 Acuerdo General 75/2008, de seis Juzgados Federales Penales Especializados en Cateos, Arraigos e Intervención de Comunicaciones.
} 
Esta revista forma parte del acervo de la Biblioteca Jurídica Virtual del Instituto de Investigaciones Jurídicas de la UNAM http://www.juridicas.unam.mx/ https://biblio.juridicas.unam.mx/bjv https://revistas.juridicas.unam.mx/ http://dx.doi.org/10.22201/iij.24485306e.2019.1.13131

tion was used amounted only 3.2 percent. ${ }^{62}$ We must then ask: are policemen detaining innocent people? Does preventive detention contribute to the fight against crime? Is preventive detention helpful for criminal investigation? Regardless the answers to these questions, the Mexican government has rejected removing this measure from the Constitution. Despite the fact that it is contrary to the protection of human rights, preventive detention is embraced in fundamental law in Mexico and it is therefore legally valid. ${ }^{63}$

More recently and consistently to a human rights protection approach, on April 6, 2018, the lower chamber of the Mexican Congress of the Union passed a bill that eliminates preventive detentions. It was a unanimous decision that gives response to the more than 10 years old international organizations demands to suppress the figure. ${ }^{64}$ Nevertheless, because the reform needs to be approved by the Senate and the local Congresses in the country, the United Nations is urging them to continue the process. ${ }^{65}$

We believe that it is the right of individuals to be part of a judicial process that offers them essential guarantees and an adequate implementation. The protections to which individuals are assured include: access to justice, the right to a process with all the essential guarantees, the right to adequate defense, the right to appeal the verdict and the right to request and ensure compliance with the final sentence ${ }^{66}$ Effective legal protection gives all people the right to gain access to the judicial branch of government in order to be able to properly exercise and defend their rights and interests. As a consequence, preventive detention in Mexico violates the right of an individual to have a legal process with full guarantees during the preliminary stage of the proceedings. We also argue that in spite of the existence of arbitrary detention in fundamental law, in the case of infringements committed by organized crime and other severe transgressions, preventive detention compromises the rule of law in Mexico, even though an "emergency measure" may be established to deal with a type of criminality in society. The State simply cannot adopt unfair proceedings which are contrary to the law, in order to investigate and reduce criminality. ${ }^{67}$

62 Leticia Pliego, Violencia-Estado en el mundo globalizado. Arraigo penal mexiCANO, UN EJEMPLO SIGNIFICATIVO (Flacso, 2014).

63 Fernando Silva, El arraigo penal entre dos alternativas posibles: interpretación conforme o inconvencionalidad 33 Magazine of Instituto de La Judicatura Federal. 240 (2012). At http:/ fundar.org. $m x /$ otrosreferentes/documentos/DocArraigoOK.pdf.

64 Andrea Meraz y Erika de la Luz, "Diputados eliminan arraigo y modifican ley de extinción de dominio", April 26TH, 2018, http://rewrexexcelsior.com.mx/nacional/diputados-eliminanarraigo-y-modifican-ley-de-extincion-de-dominio/1235154.

65 La ONU-DH pide celeridad al Senado para eliminar el arraigo, April 27, 2018 https:// wrerc.proceso.com.mx/531825/la-onu-dh-pide-celeridad-al-senado-para-eliminar-el-arraigo.

66 García, supra note 48, at 11.

67 Elías Carranza, Politica criminal y humanismo en la reforma de la justicia penal. 116 NUEva SOCIEDAD 21 (1991). 


\section{Preventive Imprisonment}

Preventive imprisonment is the placing in prison of a person who is suspected of having committed a crime when the prosecutor believes the suspect may flee from justice, harm victims or destroy evidence. As Cámara has stated, preventive imprisonment consists of the deprivation of liberty of an accused individual with the purpose of guaranteeing the process or enforcement of a sentence. ${ }^{68}$ This kind of imprisonment entails the incarceration of an individual who has not received a guilty verdict. Unfortunately, in Mexico preventive imprisonment is a growing phenomenon and it remains mandatory for wrongful activities conducted by criminal groups in a structured and systematic manner.

At first glance, preventive imprisonment has an investigatory goal, even when applied to organized crime, since in its quest for ensuring the effectiveness of criminal law, it encourages the confession of the accused or collaboration with the government investigation. On the other hand, a thorough study of preventive imprisonment suggests that the measure encourages harmful and abusive police practices that are ineffective when the suspected individual did not in fact commit the crime. ${ }^{69}$

Although in Mexican law preventive imprisonment is a precautionary measure used to initiate and perform legal proceedings, it remains a coercive legal instrument that causes financial damages, pain and suffering. ${ }^{70}$ An individual subject to this measure experiences loss of freedom, job and income loss, at the same time he or she bears the stigma of being labelled a criminal in society. Furthermore, it leaves the accused in a detached relationship with their family, whose members will likely incur new debts as a result. ${ }^{71}$

From this point of view, preventive imprisonment is equivalent to a sanction before a sentence and incarceration without judgment. Opponents of this kind of detention claim that an accused individual must be presented before the judge in a manner that ensures the dignity of the citizen, who is presumed innocent. Additionally, they emphasize it does not guarantee principles such as equality of the parties.

It has been contended that preventive imprisonment is used to make sure that certain needs of the trial are satisfied such as avoiding the danger of the accused escaping and evading justice or hindering the criminal

68 L. Címara, Medidas cautelares personales 122 (Curitiba Juruá 2011).

69 Id. at 20.

70 Javier Rodríguez, Prisión preventiva, populismo punitivo y protección de los Derechos Humanos en el sistema interamericano. in J. Llobet Rodríguez and D.Durán: Política criminal en el Estado Social de Derecho (Editorial Jurídica Continental, 2010).

71 Guillermo Zepeda-Lecuona, Los mitos de la Prisión Preventiva (Open Society Justice initiative, 2005). 
Esta revista forma parte del acervo de la Biblioteca Jurídica Virtual del Instituto de Investigaciones Jurídicas de la UNAM http://www.juridicas.unam.mx/ https://biblio.juridicas.unam.mx/bjv https://revistas.juridicas.unam.mx/ http://dx.doi.org/10.22201/iij.24485306e.2019.1.13131

investigation, ${ }^{72}$ nonetheless, these requirements are met with the individual's compulsory presentation before the judge in order to lay criminal charges. Besides, the preventive purpose of this measure has vanished since this type of imprisonment is pronounced on the bases of the list of offences considered as serious crimes and is the result of the lack of logical alternatives to prevent a person from evading justice. ${ }^{73}$

Flores has emphasized that preventive imprisonment implies that a person is incarcerated while being subject to a legal process ${ }^{74}$ and that in Mexico, authorities have made an irrational use of it. ${ }^{75}$ According to a study by the United Nations Latin American Institute for the Prevention of Crime and the Treatment of Offenders (ILANUD), by the end of the $20^{\text {th }}$ century, 61 percent of incarcerated people had not received a sentence. ${ }^{76} \mathrm{~A}$ special brief by the IACHR concluded that by 1996 more than 50 percent of inmates in Mexico had not received a sentence. ${ }^{77}$ More recently, in 2009, it was found that 41.5 percent of 210,000 inmates in Mexico were individuals who, despite having not received a sentence, are kept behind the bars and thus suffer the consequence of imprisonment. ${ }^{78}$ These prisoners are not always separated from sentenced inmates and can make connections with real, experienced and dangerous criminals, learning and being encouraged to commit crimes when they are released. ${ }^{79}$

The use of preventive imprisonment is inconsistent with Article 7 of the American Convention of Human Rights, which protects personal freedoms and prohibits arbitrary detention. ${ }^{80}$ It is also contrary to Article 9 of the International Covenant on Civil and Political Rights and by General Assembly Resolution 2200A (XXI) of 16 December 1966, which establishes that everyone has the right to liberty and security and that no one shall be subject to arbitrary arrest or detention. These international instruments recognize the

\footnotetext{
72 Id.

73 Marco Lara Klahr, Prision sin condena. Ocho historias sobre los costos sociales Del encierro preventivo en MéXico (Editorial debate, 2008).

74 VERÓNICA V. FLORES, LA PRESUNCIÓN DE INOCENCIA COMO GARANTía BÁSICA EN EL DERECHO CONSTITUCiOnal (Doctoral dissertation, 2013).

75 Jorge Garza, Marco Jurídico conceptual de la Prisión Preventiva y la farmacodePENDENCIA EN MÉXiCO, ASí COMO DE LA LIBERTAD PERSONAL EN EL ÁMBITO INTERNACIONAL DE LOS Derechos humanos. Tesis maestría en derechos humanos y democracia (FLACSO, 2014).

76 Javier Llobet Rodríguez, Prisión preventiva, populismo punitivo y protección de los Derechos Humanos en el sistema interamericano. POLítICA CRIMINAL, 183-219 (2010).

77 Informe sobre el uso de la prisión preventiva en las Américas, Comisión Interamericana de Derechos Humanos, 2013.

78 ZEPEDA-LECUONA, supra note 67 , at 8.

79 LARA KLAHR, supra note 69, at 154.

80 Douglass Cassel, El Derecho Internacional de los Derechos Humanos y la detención preventiva 21 Revista del Instituto Interamericano de Derechos Humanos 34 (1995).
} 
prevalence of the presumption of innocence over preventive imprisonment. ${ }^{81}$ The application of these norms is relevant since they are consistent with the principle of pro persona recognized by Mexico and in accordance with the norm that offers a more extensive protection of fundamental rights.

We share Beccaria's notion that imprisonment is a penalty that must be necessarily preceded by a declaration of having committed a crime, as outlined by Foucault. ${ }^{82}$ Taking into consideration that pre-trial detention is a coercive measure requiring the deprivation of freedom itself, it must be prohibited in states that recognize the presumption of innocence, when evidence is not yet presented or evaluated. Otherwise, a detainee is treated as if already found guilty at a preliminary stage of a trial. ${ }^{83}$ Additionally, it represents an abusive measure in an initial stage of a process that obstructs the exercise of an individual's defense and may result in the manipulation of evidence.

In order to understand the evolution of preventive imprisonment, it is worth reviewing several regulatory changes preventive imprisonment has gone through in Mexico. On September 3, 1993, a new law stated that authorities could determine if cautionary provisional freedom might be declared. ${ }^{84}$ During this stage, the suspect's right to cautionary provisional freedom was illusory, since it required a fee of a certain amount of money to guarantee payment of damages, such an amount was seldom at the disposal of the detainees. ${ }^{85}$ In 1996 the seriousness of the offense was calibrated to the imposition of preventive imprisonment.

After the June 18, 2008 reform it was established that this cautionary measure, imposed only in cases of serious crimes, would not be the rule, but the exception. ${ }^{86}$ The crimes that are punishable with preventive imprisonment are decided by the legislature, on behalf of the judge. ${ }^{87}$ As for organized crime, Article 19 (fourth paragraph) of the Mexican Constitution lists the type of crimes for which cautionary measures cannot be anything other than prison. ${ }^{88}$ More recently, in 2014, Article 167 of the Code of Penal Procedures applicable to the Nation (CNPP) established mandatory preventive imprisonment. ${ }^{89}$ In June 2016, changes to the Federal Act Against Organized Crime

81 Javier Llobet Rodríguez, supra note 72.

82 Michel Focault, Vigilar y castigar (18 a edición, siglo XXI, 1990).

83 Mario Corigliano, Plazo razonable y prisión preventiva a la luz de la Corte Interamericana de Derechos Humanos, 5 Derecho y Cambio social 5 (2008).

84 Guillén \& De la Cruz, supra note 28, at 322.c fvg.

85 Id. at 326.

86 Israel Flores Rodríguez, El régimen constitucional de la prisión preventiva en México: Una mirada desde lo internacional, 35 Revista del Instituto de LA Judicatura Federal, 15 (2013).

87 Article 7 of the General Law for prevention, sanction, and eradication of crime dealing with human trafficking; and with protection and assistance to victims of these crimes, imposes preventive imprisonment for individuals accused of the commission of these unlawful acts.

88 ZePEDA-LECUONA, supra note 67, at 10.

89 Intentional murder, rape, kidnapping, human trafficking and violent crimes committed 
Esta revista forma parte del acervo de la Biblioteca Jurídica Virtual del Instituto de Investigaciones Jurídicas de la UNAM http://www.juridicas.unam.mx/ https://biblio.juridicas.unam.mx/bjv https://revistas.juridicas.unam.mx/ http://dx.doi.org/10.22201/iij.24485306e.2019.1.13131

stated that preventive imprisonment will be applied to people who have committed organized crime, who will remain in jail while being processed. ${ }^{90} \mathrm{Ar}-$ ticle 42 establishes "special facilities" for individuals incarcerated as a result of either preventive imprisonment or a conviction for organized crime.

In April of 2017, members of a political party presented a legislative initiative suggesting that preventive imprisonment be used for individuals found to be in possession of weapons reserved for the exclusive use of the Army. The objective of this proposal, according to those presenting the initiative, is to provide government institutions in charge of justice with appropriate mechanisms to combat organized criminal activity. ${ }^{91}$ One of the reasons for this proposed change is that according to information from the 2016 National Survey of Victimization and Perception of Public Security, 45.2 percent of the 17.1 million crimes committed in 2015 involved weapons. In such dangerous environment, Mexican citizens expect severe punishment for those who commit serious crimes. For that reason, congress submitted an initiative to amend Mexico's Constitution, allowing judges to order preventive imprisonment for those found improperly carrying weapons reserved for the exclusive use of the Army.

The last thirty years in Mexico have seen criminal laws changed, sentences for certain crimes have been increased, as have the types of crimes that can trigger the application of preventive imprisonment. ${ }^{92}$ Evidently, most of these are serious crimes committed by groups of people engaged in planning and sustaining criminal operations. Consistent with this assertion, we observe that as Congress passed new laws regulating illegal acts carried out by organized criminal groups, preventive imprisonment became compulsory upon the apprehension of suspects believed to have participated in the commission of sophisticated wrongful acts.

Notwithstanding the previous framework, the state is the institution which must pay the risk of evidence spoliation by the accused after his or her appearance in court. ${ }^{93}$ Ferrajoli notes that this is a cost that the criminal justice

through violent means such as weapons and explosives, as well as serious crimes determined by law concerning national security, law against the free development of personality and health. Mara Gómez Perez, La prisión preventiva en el código nacional de procedimienTOS PENALES, (JURIDICAS UNAM, 2015) available at https://archivos.juridicas.unam.mx/wrwr/bjo/ libros/9/4032/22.pdf visited 11 october 2017.

90 Ley Federal contra la Delincuencia Organizada of 2016. http://gaceta.diputados.gob.mx/ PDF/63/2016/jun/20160614-III.pdf visited 1 march 2017.

91 See http://wrerc.milenio.com/leon/ley-armas-delito-diputados-guanajuato-milenio-noticias-leon_0_946105774.html.

92 Guillermo Zepeda Lecuona, Informe general seguimiento del proceso de implementación de la reforma procesal penal en México. Estados de Chinuahua, Estado de México, Morelos, OAxaca y Zacatecas, 2007-2011 (USAID-Ceja Américas, 2012).

93 Luigi Ferrajoli, Derecho y razón teoría del garantismo penal, $\left(6^{a}\right.$. Edición Editorial Trotta, 2004). 
system must pay, if it wants to safeguard basic rights, fairness and its raison d'etre. Based on the analysis above, it can be concluded that in a country that respects the fundamental rights of those that reside within its borders, the punitive powers of the state can be exercised only once a competent judicial authority has found a defendant guilty (and not before), regardless of the acts of an individual subject to a criminal investigation. Preventive measures must serve a last resort, imposed only if no less restrictive means exist, and they must be always subject to judicial oversight. An indicted person must face trial in freedom and not deprived of it. ${ }^{94}$ In this sense, the imposition of preventive imprisonment must not be the result of irrational use of criminal justice institutions; otherwise, the fact that an individual spends time in jail implies the application of an anticipated and unjustifiable penalty.

As we can observe, the worrisome and rapid growth of organized crime in Mexico has given birth to a regime of exemptions, conceived as a response to criminal activity. Such a regime consists of the application of arbitrary detentions and restrictions of freedom, resulting in sanctions being meted out to people who have not been sentenced by a judicial authority. Contradictorily, at the same time as these freedoms are restricted, Mexico is oriented towards democratization, which is understood as a process in which the state, through the recognition of rights for its citizens, enhances freedom.

Criminal justice policy that violates human rights has been created in México. Supporting this paper's hypothesis, we perceive two types of regulations in the Constitution: one protecting individual rights and the other advancing norms allowing severe infringements on these rights, as contained in the Federal Act Against Organized Crime. The inclusion of these norms and methods signifies that the rule of law is toothless when it comes to facing criminal groups. Does this mean that the country is adopting an exceptional regulation, specifically a "combat norm" in which the breach of the rule of law is acceptable? Clearly, measures that restrict freedom and make cruel treatment legal are distant from those of a country where human rights are respected. ${ }^{95}$ In Mexico, we have introduced in the law an incomprehensible justification to rights violations, which gives the state and its authorities the authority to strongly infringe the right to personal freedom. ${ }^{96}$ It translates into a policy that defeats the guarantees of the criminal justice laws which it intended to migrate.

Ironically, the Constitution protects human rights and sets out a fair criminal justice process at the same time as it allows for arbitrary actions in or-

\footnotetext{
94 Id.

95 Ricardo Morales, El derecho a la intimidad: grabaciones con videocámaras y microfonía oculta 4 LA LEY: REVISTA JURÍDICA ESPAÑOLA DE DOGTRINA, JURISPRUDENCIA Y BIBLIOGRAFÍA 1718-1725 (2004).

96 Raúl Plascencia, Las Comunicaciones Privadas y la Reforma Penal in REForma constitucioNAL Y PENAL DE 1996 (Instituto de Investigaciones Jurídicas de la UNAM, 1997).
} 
der to fight organized crime. ${ }^{97}$ Authorities are then justified in investigating a harmful, and growing phenomenon using arbitrary methods. This puts the rule of law in crisis, since no one should be prosecuted in an atmosphere in which there are no rights, i.e., criminals should not be investigated through restrictive measures that permit the state to lower itself to the level of transgressors of the law. Therefore, we must consider whether or not there has been a dilution of the principles that protect human rights in the law itself. Is the promotion and acceptance of a norm allowing arbitrary acts the result of the government's inability to guarantee collective security? In any event, the above should not occur in a country where the rule of law is functioning.

Hassemer and Muñoz Conde have stated the purpose of criminal justice is not only to protect legal interests and social coexistence but also to limit the powers of the state to impose severe sanctions that diminish minimum guarantees. ${ }^{98}$ In line with this, we sustain that democracies fail in states when authorities are permitted to carry out investigations that compromise freedom, dignity, privacy, and property. Consequently, a country cannot resort to illegal procedures in order to maintain order and peace; a country must not resort to the methods that are used by criminals in order to defeat them.

Even in societies affected by violence and high crime rates, the response to criminality should not consist of limitations on the constitutional freedom of citizens. Laws must guarantee limitations in criminal investigations, as well as the punitive function of the state, in order to prevent arbitrary actions and abuses affecting human rights. Following this analysis, we do not object to the fact that in a criminal investigation authorities need to put in place effective procedures in order to obtain the elements necessary to attain a conviction and demonstrate an illegal act. ${ }^{99}$ Such mechanisms, however, need to respect the legal sphere of the citizen and safeguard inherent human rights, such as freedom; otherwise the system would upset the presumption of innocence.

Paradoxically, the Mexican Constitution has created norms that are inconsistent with the rule of law in such a way that different legal practices sanctioned by Mexican laws run contrary to due process and the rights to freedom and privacy. With the inclusion of the norms that allow for preventive detention and preventive imprisonment, what happens to the guarantees of the new criminal procedure that among other aims, is intended to help avoid arbitrariness and abuse on the part of the authorities, so that justice becomes more humane?

It was already mentioned that the decision of the Supreme Court in Case 293/2011 established that the Constitution must prevail when a legal provi-

\footnotetext{
97 Emiliano Borja, Gurso de política criminal (Tirant lo Blanch 2003).

98 Winfried Hassemer \& Francisco Muñoz, Introducción a la criminología y aL DERECHO PENAL, (Tirant lo Blanch 1989).

99 Blanca M. Buergo, Exigencias de la moderna política criminal y principios limitadores del Derecho penal 52 AnUario de Derecho PENAL y Ciencias PENALES, 289 (1999).
} 
sion in an international treaty and the Carta Magna are not consistent. The next step in this analysis is to determine the consequence of having two types of constitutional norms: one protecting and the other one infringing on human rights. Is it possible that one constitutional legal provision is superior to another? We must then analyze how both types of legal provisions, that is, the ones protecting human rights and the ones regulating preventive detention as well as preventive imprisonment, have followed the same legislative process established by Article 135 of the Mexican Constitution. According to this Article, one constitutional norm cannot be superior to another.

One of the solutions to this problem in the application of the law is provided by the "constitutional contradictions interpretation doctrines." 100 With these doctrines in mind, the judicial officer must identify the constitutional inconsistency. For "ideological contradictions", a succeeding law derogates a previous law. In the Mexican context, for example, the 2011 human rights reform should prevail in any interpretation, since it supports the most recent social ideology and enlightens the rest of the constitutional text. ${ }^{101}$ According to the "unconstitutional constitutional law doctrine," the judge must not apply legal provisions infringing basic human rights since they are considered "inappropriate law." Conforming to the "preferred liberties doctrine" means that while some values are in conflict in the text, the superior constitutional rights of freedom and due process should prevail. ${ }^{102}$ Pursuant to the "balancing test" doctrine, the coexistence of different values in the constitutional text suggest the judiciary evaluate and infer the commitment or vocation of the Constitution. ${ }^{103}$ Finally, in consonance with the "democratic interpretation doctrine" a conflict between rights and values established in a constitutional text should be interpreted in a republican and democratic sense, that is, in the most favorable way possible for human beings. These are constitutional interpretation guidelines that should guide the Supreme Court of Justice or the Constitutional Courts, who are the ones applying the norm.

Another solution is expressed in the criteria of The Mexican Supreme Court of Justice, stating that judges have to compare between constitutional legal provisions before deciding to apply one of them in a specific case. In consonance with the method of judicial interpretation called: "conventionality control ex oficio" (in Spanish: "control de convencionalidad ex oficio") judicial officials should prefer to interpret a legal provision in a sense which is consistent with the human rights established by the Constitution and international treaties. ${ }^{104}$ Besides, Article 1 of the Carta Magna and Article 29 of American

100 Nestor Pedro Sagus, La interpretacion judicial de la Constitución. De la Constitución nacional a la Constitucion convencionalizada (Porrúa, 2016).

101 Id. p. 142.

102 Id. p. 145.

103 Id. p. 146.

104 PASOS A SEGUIR EN EL CONTROL DE CONSTITUCIONALIDAD Y CONVENCIONALIDAD EX OFFICIO 
Esta revista forma parte del acervo de la Biblioteca Jurídica Virtual del Instituto de Investigaciones Jurídicas de la UNAM http://www.juridicas.unam.mx/ https://biblio.juridicas.unam.mx/bjv https://revistas.juridicas.unam.mx/ http://dx.doi.org/10.22201/iij.24485306e.2019.1.13131

Convention of Human Rights establish a system to interpret human rights according to which the legal provisions that offer the best protection to human beings must prevail. ${ }^{105}$

\section{IACHR RECOMMENDATIONS}

Following up on justice procurement and transgressions of human rights in Latin America, the Inter-American Commission on Human Rights (IACHR) emphasizes that Article 2 of the American Convention calls for the suppression of legal provisions and practices violating the guarantees established in the Convention as well as the promulgation of legal provisions advocating full observance of legal guarantees. ${ }^{106}$ The IACHR has recognized that states must conduct research on the violation of rights protected by this instrument, including due process and judicial protection. ${ }^{107}$ It also reaffirms that whenever state authorities are aware of activities that infringe on human rights protected by the Convention, they must follow up on such practices in an effective way so that perpetrators may be prosecuted and punished, regardless of the agent violating such individual rights. In this respect, when state authorities are involved in the misconduct, states must clarify the facts and render judgment. ${ }^{108}$ In addition, in the case of more severe human rights transgressions, such as torture, arbitrary detentions and the enforced disappearance of persons, eliminating responsibility is inadmissible and amnesty is not possible. ${ }^{109}$

Contrary to these observations, between 2010 and 2015 Mexico received more than 2,000 torture complaints. ${ }^{110}$ In 2015 Mexico reported to the Attorney General that out of the 2,420 cases of torture opened, only 15 cases had achieved convictions. ${ }^{111}$ Consequently, the CNDH issued 256 recommendations regarding torture and 442 regarding cruel, inhuman or degrading treat-

en materia de derechos humanos. Pleno, Semanario Judicial de la Federación y su Gaceta, Décima Epoca, libro III, Diciembre de 2011, No. 160525, p. 552. Mexico.

105 Fernando Silva García, Principio pro homine vs Restricciones constitucionales. ¿Es posible constitucionalizar el autoritarismo? 269 (Porrúa 2016).

106 OEA/Ser.L/V/II. Doc. 5731 diciembre 2009, p. 18.

107 According to article 1.1 of the American Convention on Human Rights.

108 OEA/Ser.L/V/II. Doc. 5731 diciembre 2009, p. 19. Corte I.D.H., Caso de la Masacre de Pueblo Bello vs. Colombia. Sentencia de 31 de enero de 2006,Serie C No. 140, párrafo 143; Caso Heliodoro Portugal vs. Panamá. Excepciones Preliminares, Fondo, Reparaciones y Costas. Sentencia de 12 de agosto de 2008, Serie C No. 186, párrafo 144; y Caso Valle Jaramillo y otros vs. Colombia. Fondo, Reparaciones y Costas, Sentencia de 27 de noviembre de 2008, Serie C No. 192, párrafo 101.

109 OEA/Ser.L/V/II. Doc. 5731 diciembre 2009, p. 19.

110 Información del Estado mexicano, visita de la CIDH, 25 de septiembre de 2015, p. 13.

111 According to informe sobre la situación de derechos humanos en México 2016. at http://wrere.oas.org/es/cidh/prensa/comunicados/2016/023.asp visited 3 December 2017. 
ment. Surprisingly, those complaints remain unpunished. The unwillingness to prosecute and sanction the government authorities who engage in those acts is clear.

According to the IACHR, in order to combat criminality, public security policies must limit state interventions by including human rights standards, even in violent societies with high levels of criminality that affects the rule of law. ${ }^{112}$ Therefore, public security policies must include human rights protections not only in legal provisions but also in practice, so that states can assume the obligations of the Inter-American System. ${ }^{13}$ The IACHR has also affirmed that states must obtain information on their criminal investigations methods in such a way that they can be evaluated permanently. Additionally, there must be proper admission, selection and training mechanisms for state authorities. The IACHR affirms that the departments in charge of public security must work with officials trained in related areas so that they can make proper decisions, ${ }^{114}$ and work not only by responding to growing levels of crime and insecurity but also by preventing organized criminality. Likewise, there must be a system to modernize police as part of the construction of a democratic society; consequently police must be encouraged to act according to human rights protection standards and the rule of law. This will help to eliminate impunity and increase the trust of society in governmental institutions.

Having studied the human rights transgressions contained within the justice procurement system, Table 1 pinpoints the legal provisions and tactics used to fight organized crime that infringe on international treaties.

\section{Table 1. Internationally Protegted Human Rights}

\begin{tabular}{|c|c|c|c|}
\hline $\begin{array}{c}\text { WHAT RIGHTS } \\
\text { DO THESE } \\
\begin{array}{c}\text { INTERNATIONAL } \\
\text { PROTECTES }\end{array}\end{array}$ & $\begin{array}{c}\text { UNIVERSAL } \\
\text { DEGLARATION } \\
\text { ON HUMAN } \\
\text { RIGHTS }\end{array}$ & $\begin{array}{c}\text { COVENANT } \\
\text { ON GIVIL AND } \\
\text { POLITICAL } \\
\text { RIGHTS }\end{array}$ & $\begin{array}{c}\text { AMERICAN } \\
\text { GONVENTION } \\
\text { ON HUMAN } \\
\text { RIGHTS }\end{array}$ \\
\hline RIGHT TO FREEDOM & Article 3 & Article 9.1 & Article 7.1 \\
\hline $\begin{array}{c}\text { PROTECTION } \\
\text { DETENTION OR } \\
\text { IMPRISONMENT }\end{array}$ & Article 9 & Article 9.1 & Article 7.3 \\
\hline
\end{tabular}

112 CIDH, Informe Anual 2003, Capítulo IV, paragraph 33 at OEA/Ser.L/V/II. Doc. 57 December 31, 2009, p. 21.

113 Id. 32.

114 Id. 34. 


\section{Conclusions}

The phenomenon of criminality in Mexico has created a risk to the security of citizens to such a degree that the country has found itself making legal exceptions to the general application of fundamental rights. The practices mentioned in this paper clearly violate human rights, including right to personal freedom, the right to free movement, due process, the right to be protected from arbitrary interference and the restriction of guarantees, as well as the principles of pro persona, the principle of legality, and the principle of legal certainty. As has been demonstrated, Mexico gives more importance to the fight against organized crime through the adoption of repressive mechanisms than to the strict protection of human rights of those suspected of participating in criminal activities.

Mexico has justified the adoption of exceptional measures within the national Constitution as necessary in order to fight criminal organizations. These measures have strengthened punitive resources, which have been eroded or reduced. Given high levels of public insecurity, Mexico needs to recognize that reducing violence and corruption are priority issues on which the country should take a stand, however, strategies to achieve this purpose need to adopt procedures to monitor the respect of human rights in the fight against organized crime.

Keeping in mind that Mexican public security policies frequently restrict human rights, legal regulations must balance authorities' powers and the protection of individual rights, and there must be a clear role for authorities in charge of public security. For instance, a stronger emphasis should be placed on prevention, rather than on repression. The law must also emphasize the absolute prohibition of torture and cruel, inhuman or degrading treatment, arbitrary detentions and the arbitrary use of force. Accordingly, authorities in charge of criminal investigations must be trained so that they act with respect for human rights, especially regarding personal freedoms. The Mexican government must also study and follow up on the effectiveness of police measures used to obtain information regarding criminal groups and to reduce the high rates of felonies.

In the international context, Mexico should reaffirm its commitments to international treaties and respect the participation of United Nations (UN) agencies. In this regard, Mexico needs to take into consideration the UN briefs recommending it avoid repressive governmental actions and strengthen democratic institutions to combat crime, as well as respecting UN reports analyzing the consequences of security policies that could lead to a decrease in violence while promoting public security without affecting human rights.

On a regional level, Mexico needs to be aware that the rights protected in the Inter-American system should not be suspended. According to the IACHR, respect for the rule of law, legality, dignity, equality and non-discrimination against individuals are principles that establish limits for state authori- 
ties intending to confront criminality and violence. It would be fruitful for the Mexican state to work together with civil society, academia and specialized independent organizations to research cases of human rights violations and to suggest how state authorities can combat criminality.

Last but not least, in sharp contrast to the Internal Security Law (Ley de Seguridad Interior), Mexico must encourage the non-participation of the armed forces in matters that correspond to the domain of policing. It is a noticeable challenge that security and organized crime policies need to be consistent with the respect to human rights and the due process, in order to ensure an effective functioning of the justice system. Public security problems in Mexico cannot be addressed by restricting the fundamental rights of the population, subsequently; state authorities should not allow for the coexistence of a legal regime consisting of the application of interventions and sanctions contrary to the protection of human rights when its democratic system is still under construction. 